\title{
RECEIPTS AND INCOME OF HOUSEHOLDS IN POLAND
}

\author{
Joanna Maria Kozak ${ }^{1 凶}$, Aldona Mrówczyńska-Kamińska ${ }^{1}$ \\ ${ }^{1}$ Poznań University of Life Sciences, Poland
}

\begin{abstract}
This article aims to assess the income situation of households in Poland, considering the level of receipts and income as well as their dynamics and structure. An analysis was also carried out with respect to differences between particular socio-economic groups and between households depending on the number of persons in a household. The Gini coefficient was used for analytical purposes. Moreover, an attempt was made to identify the causes of income diversification. The analysis was carried out based on data derived from household budget surveys conducted by Statistics Poland. The research covered the period from 2000 to 2019 (individual years). The study showed a real increase in the average monthly net receipts and available income in all households. The most favourable financial situation was observed in white-collar workers, self-employed persons and one-person households. The least favourable income situation was found in households of bluecollar workers and pensioners and households of six or more persons. However, attention should also be paid to changes taking place in the structure of sources of income generated by household members. There is an increase in income from hired work and social assistance benefits. The highest variations in receipts and available income were observed in households of farmers and those of six or more persons. In contrast, the smallest variations were recorded with respect to households of old-age pensioners and one-person households.
\end{abstract}

Keywords: household, net receipts, available income, savings on the revenue side, income range, income diversification

\section{INTRODUCTION}

Apart from enterprises, households are the basic units creating the economy, which actively participate in processes taking place in the economy (Drymluch i Chorkowy, 2009). They are described as the world's oldest sustainable economic institution (Światowy, 2012; Urban, 2016). They are created by one person or a group of people living together who share common income (resources) and expenses, guided by the satisfaction of the needs of all its members and characterised by joint activities (Casimir and Tobi, 2011). Households provide a productive factor, i.e. work, without which management would not exist; they also verify the goods and services produced through their acquisition and physical consumption (Świetlik, 2011). They perform the production and supply function, the consumption function, and the social function (including reproductive and educational function). Their members make their own decisions, taking their own needs into account and accepting the risks involved. In view of an improving economic situation, it is important how funds are generated and managed. Money generated by the household members in exchange for the provision of services constitutes the factor determining their survival and proper functioning. The income reflects their knowledge, qualifications and work. It is used mainly for consumer goods and services and savings (Świetlik, 2011).

The quality and way of life of the Polish society forming households were influenced by changes arising from the system transformation. Such changes resulted, among other things, from the modernisation of society, the spread of new values and behavioural patterns from Western Europe (Inglot-Brzęk, 2010). Moreover, an increasing rate of economic growth caused, for instance, by the accession of Poland to the European

\footnotetext{
Joanna Maria Kozak, Department of Economics and Economic Policy in Agribusiness, Poznań University of Life Sciences, Wojska Polskiego 28 St., 60-637 Poznań, Poland, e-mail: joanna.kozak@up.poznan.pl, https://orcid.org/0000-0002-0500-2406
} 
Union had a positive impact on the financial situation of households.

The household income survey is mostly important because of the economic and social role it performs. This role mainly results from the fact that household income is an essential factor determining the demand and the consumption level in the economy (Gasińska, 2016).

The financial situation of household members depends on a number of factors. Factors that determine the value and structure of income and affect the obligatory public charges of household members and income disparities mainly include the economic activity of individuals forming households, the tax burden on the income and social security contributions. The place of residence, education, demographic factors, the state's fiscal policy, and the changing situation on the labour market are also important in this respect (Mazurek-Krasodomska, 2017). It is often pointed out that the level of social trust and sense of security significantly affect the proper functioning of households (Kramer, 2004). Fig. 1 shows the most important macroeconomic factors that significantly impact the financial situation of households. The most important factors include the GDP growth rate, GDP per capita, inflation rate, savings, unemployment, consumption expenditure and consumer loan value (Świecka i Musiał, 2014). Macroeconomic indicators determine other environmental elements and influence the sense of security and trust in the structures, state and local governments (Kramer, 2004; Grzega, 2007).

The increasing real GDP value is a synthetic measure of economic growth and a value indicating societal needs. One way to measure GDP is to count the total income from production factors that has been paid to households by companies. The factors determining the amount of GDP include the expenditures incurred by various economic entities on goods and services or total income earned by such entities. Therefore, the increasing level of GDP improves the standard of living of household members; in other words, it contributes to higher income that can be spent on various goods and services (consumption expenditure) and, consequently, support enterprises (Śleszyńska-Świderska, 2014).

The situation of households also depends on interest rates which affect credits and savings. The development in interest rates influences not only the cost of credit but also the expected rate of return. Lower interest rates entail higher creditworthiness of households (credits are cheaper and more accessible, households pay lower credit instalments) and reduce their willingness to save because of lower rates of return on deposits, which in turn involves higher interest rates on savings deposited by the society. The household savings rate determined by the inflation and unemployment rate consequently affects economic stability in the short run, and economic growth in the long run (Ögren, 2018).

The study on the financial situation of households plays a vital role in the observation of the population standard of living. Therefore, the income and receipts of households are examined in many studies. Michorowski et al. (2016) studied the income of households in economic and social groups from 1993 to 2014 and showed that there was a real increase in average monthly available income in all groups. The lowest income was generated by farmer households, whereas the households of self-employed persons were in the best financial situation. The authors observed that the structure of income sources changed and that the share of income from hired work (except for pensioner households) increased. In contrast, the share of income from social assistance benefits decreased. On the other hand, the identification of household income diversification in Poland, carried out by Muszyńska (2006), to assess the level of dispersion of household income, showed that Polish households were significantly diversified in terms of income. According to the research included in the above article, the amount of income is affected by the fact that households belong to different economic and social groups and have

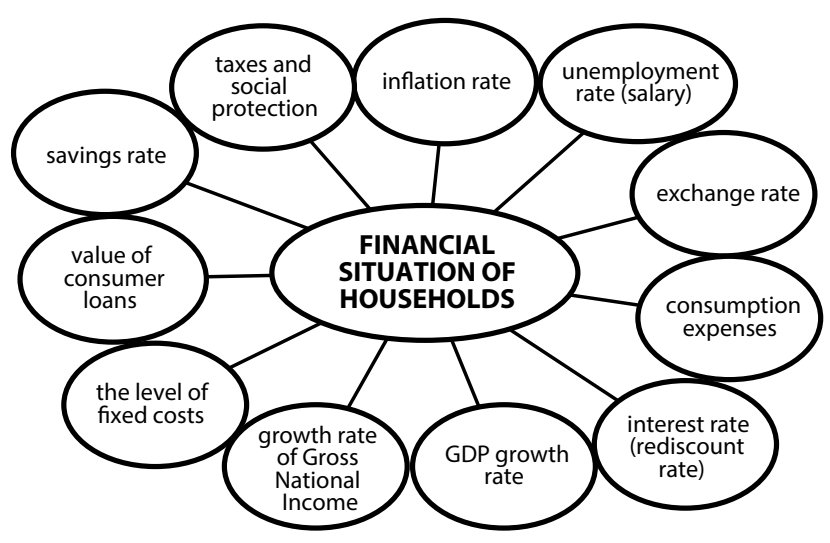

Fig. 1. Macroeconomic factors determining the financial situation of households

Source: own study based on Świecka and Musiał, 2014; Kramer, 2004. 
a varied number of members. It mainly influences the way of living of individuals forming a household and the possibilities of satisfying their individual and common needs. The social stratification in terms of the available income is permanent or even increases with time (Muszyńska, 2006). The study on household income structures showed that all economic and social groups are looking for additional income sources (financing), which was confirmed by the increasing ratio of income generated from sources other than the main one to the available income of households in Poland. According to Pochopień and Rykowska (2013), after Poland acceded to the European Union, there was a slowdown in income diversification growth; however, this does not mean that such disparities do not occur. An important factor in determining the financial situation of households is their debts. According to Wiśniewska (2016), apart from the consumer lifestyle, the causes of excessive debts include additional cash streams and benefits, which allow households to regulate and incur liabilities. According to the research, higher available income, increased by government household support programmes (such as the Family 500+ Programme), leads to over-indebtedness. Family-friendly benefits also increased the amount and share of expenditures for food needs in total expenditures. In general, social assistance has a significant impact on household economic activity because it partially increases the available income and income per capita.

\section{MATERIAL AND METHODS}

The main objective of this article is to assess the income situation of households in Poland, considering the level of receipts and income as well as their dynamics and structure. The financial situation of households was determined, taking into account economic and social groups and the number of persons in a household from 2000 to 2019. The analysis was carried out with respect to households included in the household budget surveys conducted by Statistics Poland and concerned the level and structure of their net receipts and available income. The primary measures of descriptive statistics (i.e. structure and dynamics indicators) and the deflation procedure were used, making it possible to adjust the current values of income and expenditures for inflation. Net receipts and available income of households were defined using the primary measures of position and variation. Their changes were presented using the average annual rate of change, determined on the basis of all time-series expressions (Wysocki and Lira, 2005).

The data on household income and outgoings collected systematically for a certain period form a household budget (Table 1). Net receipts are all the amounts that flow into the household. They consist of available income and savings on the revenue side. Available income includes income from hired work, private farms in agriculture, self-employment except for private farms in agriculture, freelance professions, ownership, rental of properties and social security benefits, and income from social assistance benefits and other income, including gifts and maintenance. The available income also includes an increase in savings. It is derived from the disposable income that households allocate to purchase consumer goods and services and an increase in savings (Statistics Poland, 2011).

Net outgoings are all the amounts that flow out of the household. They consist of expenditures and savings on the outgoings side. Net receipts and net outgoings do not include advances on personal income tax and social security and health insurance contributions.

Table 1. Household budget

\begin{tabular}{lc}
\hline \multicolumn{1}{c}{ Net receipts } & Net outgoings \\
\hline Available income: & Expenditures: \\
- income from hired work & - consumer goods and \\
- income from self-employment & services: \\
- income from private farms in & - other expenses \\
agriculture & Savings: \\
- income from ownership & - deposits paid, including \\
- income from the rental of & the purchase of securities \\
properties & - loans and credits paid \\
- income from social security & - cash loans granted to other \\
benefits & households \\
- income from social assistance & - life insurance premiums \\
benefits & - purchase, repair and \\
- other income & modernisation of tangible \\
Savings: & assets \\
- deposits collected, including & \\
the sale of securities & \\
- loans and credits taken & \\
- repayment of cash loans grant- & \\
ed to other households & \\
- life insurance benefits & \\
- sale of tangible assets & \\
- sale of used consumer goods & \\
\hline
\end{tabular}

Source: own study based on household budgets, 2016 . 


\section{STUDY RESULTS}

When analysing the financial situation of households, it should be noted that from 2000 to 2019 , the financial situation of households improved. Its main determinant is the higher income per capita (Fig. 2). The average monthly net receipts per person (Fig. 2) in total households were over PLN 2,300 in 2019. They were higher in real terms by ca. $83 \%$ compared to receipts in 2020 , caused by increasingly higher income from hired work and social assistance benefits. The average monthly available income per capita in 2019 amounted to ca. PLN 1,800 and was higher in real terms by over $99 \%$ compared to income recorded in 2020. Net receipts and available income in Polish households demonstrated variations at the level of $20 \%$ and $23 \%$, respectively, which may indicate income diversification in households resulting from the fact that households belong to different economic and social groups and comprise a varied number of members. The average annual rate of change in receipts and income was at the level of ca. $3 \%$ and $3.5 \%$, respectively (Table 3 ) and resulted from economic growth. The medium-term rate of change of gross domestic product and GDP per capita after adjustments for inflation was at the level of ca. 3.7\% in the analysed years (authors' calculations based on annual macroeconomic indicators, Statistics Poland).

Income from hired work, i.e. $48 \%-55 \%$, and income from social security benefits (ca. 24-28\%) accounted for the largest share in the average monthly available income of households per capita in all the surveyed years (Fig. 3). In 2019, income from hired work increased by more than $116 \%$, and income from social security benefits increased by nearly $79 \%$ compared to 2000 . In the analysed years, the highest increase in household member income was generated from social assistance benefits (nearly 203\%) (Table 2).

The income from deposits and obtained loans and credits constitutes a substantial source of additional funds for households. Funds obtained from deposits and loans and credits and other funds are recorded as savings on the revenue side. In 2019, savings on the revenue side amounted to PLN 502 per capita, which is ca. $42 \%$ more funds than in 2000 (PLN 354.31 per capita).

In all the analysed years, there was an increase in real income in all economic and social groups (Fig. 4). The highest average real net receipts were achieved by white-collar workers and self-employed individuals, i.e. ca. PLN 2,800 and ca. PLN 2,700, respectively, in 2019. Net receipts in these groups in 2019 increased by ca. $46 \%$ and $77 \%$ compared to 2000 . The highest levels of income generated by the households of white-collar workers and self-employed individuals resulted from their higher education level or specialised professional skills compared to other economic and social groups (Kozera and Wysocki, 2014).

On the other hand, the lowest real average net receipts in all the analysed years were achieved by blue-collar workers and pensioners, i.e. more than PLN 1,890 and PLN 1,900 in 2019. The highest increase of real average

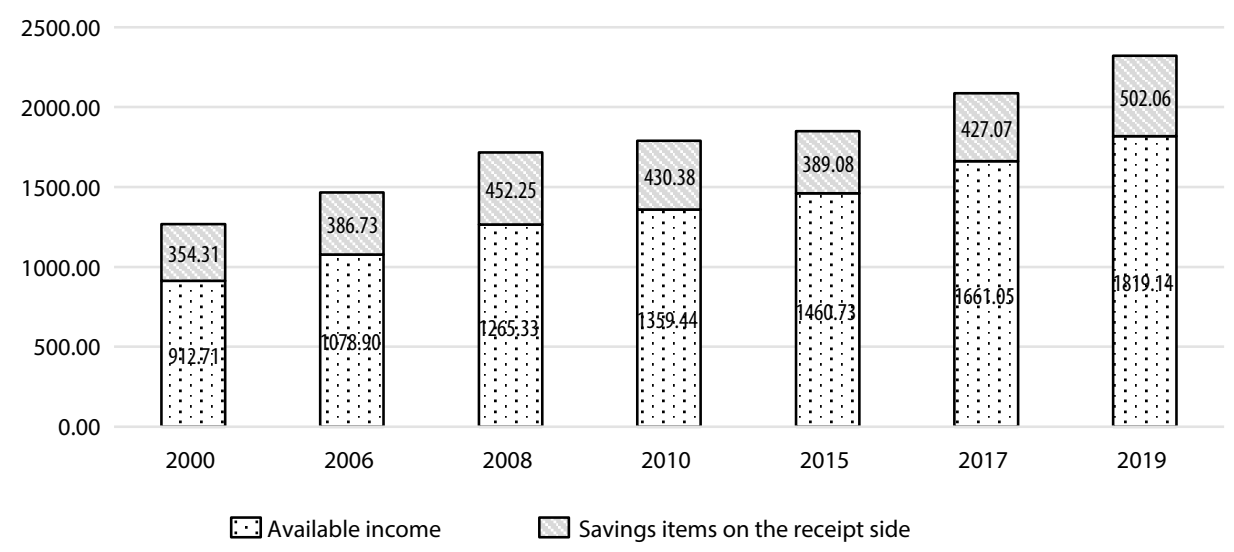

Fig. 2. Average monthly net receipts in real terms per capita in total households in Poland from 2000 to 2019 (PLN)

Source: own study based Statistics Poland, 2001; 2007; 2009; 2011; 2016; 2018; 2020. 
Kozak, J. M., Mrówczyńska-Kamińska, A. (2021). Receipts and income of households in Poland. J. Agribus. Rural Dev., 1(59), 101-115. http://dx.doi.org/10.17306/J.JARD.2021.01431

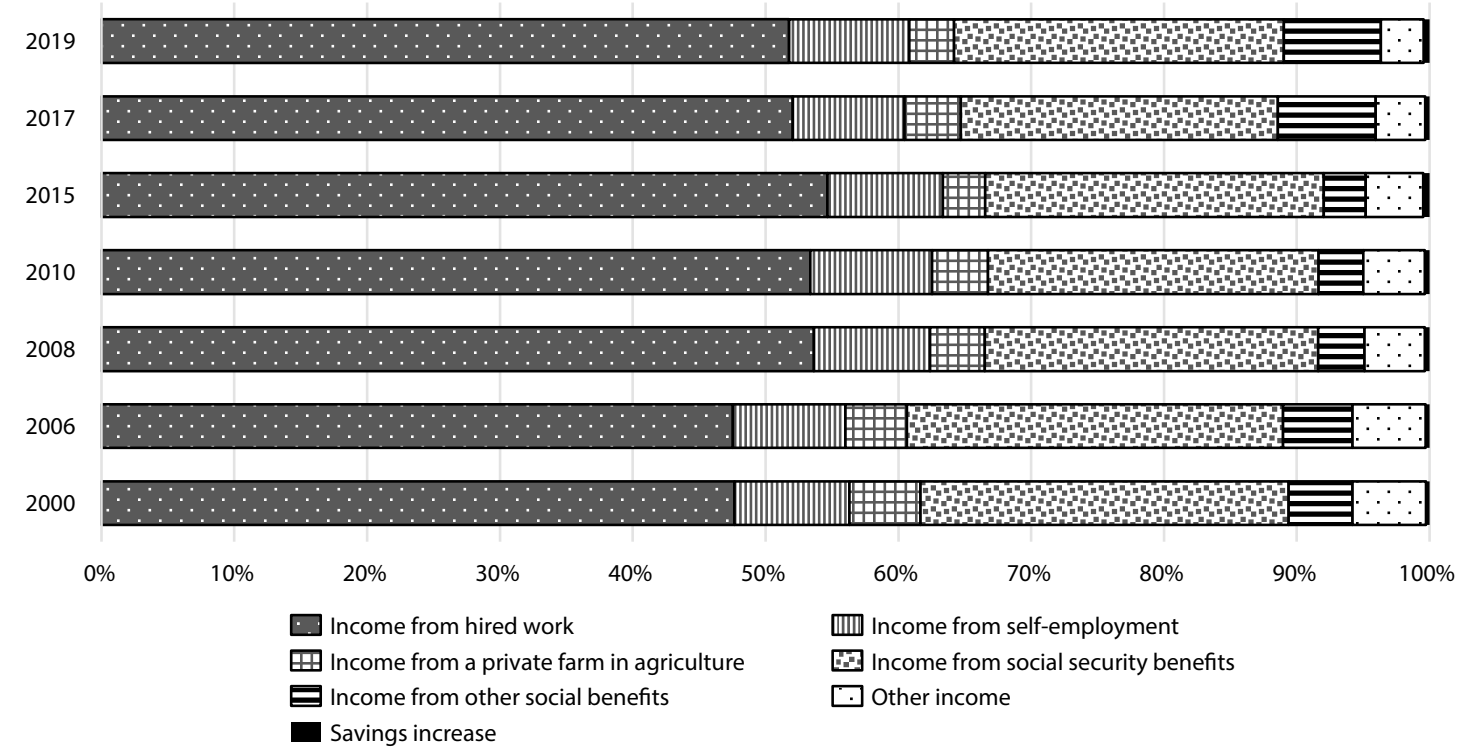

Fig. 3. The structure of average monthly available income per capita in total households in Poland from 2000-2019 (\%)

Source: Statistics Poland, 2001; 2007; 2009; 2011; 2016; 2018; 2020.

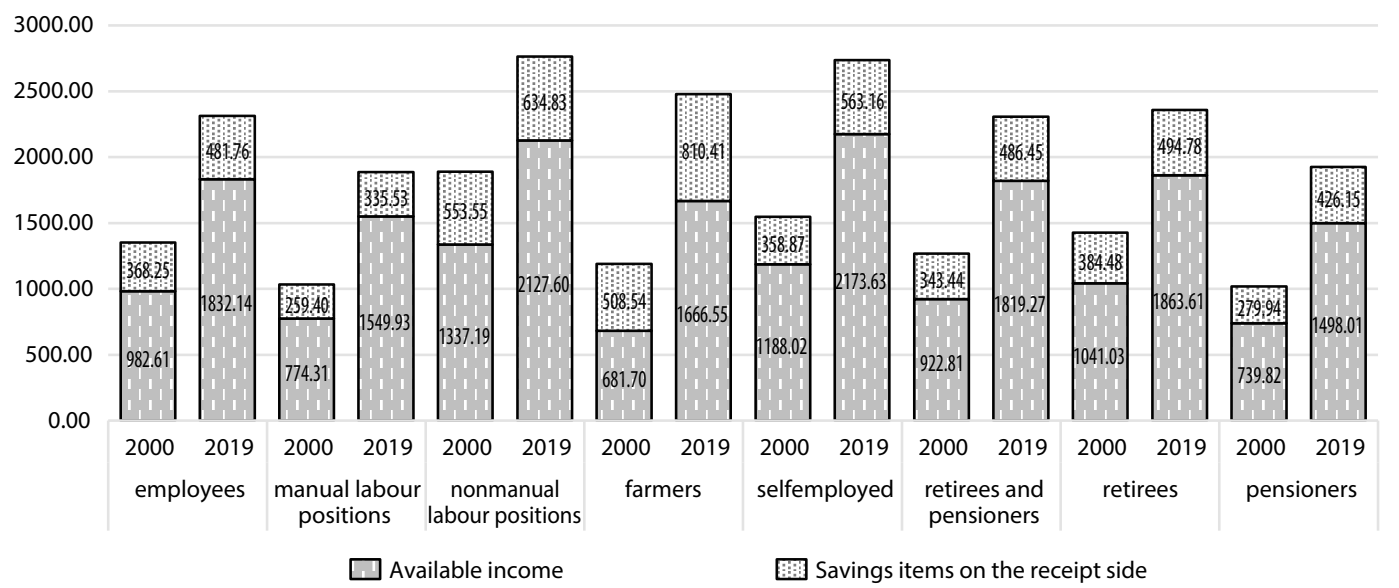

Fig. 4. Average monthly net receipts per capita in real terms in households by economic and social groups in Poland in 2000 and 2019 (PLN)

Source: own study based on Statistics Poland, 2001; 2020.

net receipts in 2019 compared to 2000 was recorded for farmer households, i.e. more than $108 \%$, and the lowest for households of white-collar workers, i.e. more than $46 \%$ (Table 3 ). Thus, real net receipts and income generated by farmers demonstrated the highest variation compared to other economic and social groups (over
$23 \%$ and almost $31 \%$ ), and the lowest variation was observed for households of white-collar workers (ca. 13\% and $16 \%$ ) (Table 3). Net receipts and income in farmer households were also characterised by the highest average annual rate of change (ca. 3.7\% and 4.6\%). The type of conducted activities, the production intensity, 
Kozak, J. M., Mrówczyńska-Kamińska, A. (2021). Receipts and income of households in Poland. J. Agribus. Rural Dev., 1(59), 101-115. http://dx.doi.org/10.17306/J.JARD.2021.01431

Table 2. Dynamics of changes in the total average monthly net receipts per person in households by the number of persons in the household and by economic and social groups in Poland in 2019 compared to 2000 (\%)

\begin{tabular}{|c|c|c|c|c|c|c|c|c|c|c|}
\hline $\begin{array}{c}\text { Type of } \\
\text { household }\end{array}$ & $\begin{array}{l}\text { Net } \\
\text { receipts }\end{array}$ & $\begin{array}{l}\text { Dispos- } \\
\text { able } \\
\text { income }\end{array}$ & $\begin{array}{l}\text { Income } \\
\text { from } \\
\text { hired } \\
\text { work }\end{array}$ & $\begin{array}{l}\text { Income } \\
\text { from self- } \\
\text { employ- } \\
\text { ment }\end{array}$ & $\begin{array}{l}\text { Income } \\
\text { from } \\
\text { private } \\
\text { farms in } \\
\text { agricul- } \\
\text { ture }\end{array}$ & $\begin{array}{l}\text { Income } \\
\text { from } \\
\text { social } \\
\text { security } \\
\text { benefits }\end{array}$ & $\begin{array}{l}\text { Income } \\
\text { from } \\
\text { social } \\
\text { assistance } \\
\text { benefits }\end{array}$ & $\begin{array}{l}\text { Other } \\
\text { income }\end{array}$ & $\begin{array}{l}\text { Increase } \\
\text { in savings }\end{array}$ & $\begin{array}{l}\text { Savings } \\
\text { on the } \\
\text { revenue } \\
\text { side }\end{array}$ \\
\hline In total & 183.20 & 199.31 & 216.46 & 208.60 & 125.67 & 178.50 & 302.52 & 116.06 & 332.08 & 141.70 \\
\hline \multicolumn{11}{|c|}{ By economic and social groups } \\
\hline Workers & 171.29 & 186.46 & 184.98 & 220.19 & . & 179.93 & 359.55 & 96.68 & 256.76 & 130.83 \\
\hline $\begin{array}{l}\text { Employees } \\
\text { at blue-collar } \\
\text { positions }\end{array}$ & 182.40 & 200.17 & 195.73 & 166.83 & . & 212.23 & 359.73 & 114.44 & 379.04 & 129.35 \\
\hline $\begin{array}{l}\text { Employees at } \\
\text { white-collar } \\
\text { positions }\end{array}$ & 146.10 & 159.11 & 158.90 & 195.84 & . & 142.26 & 397.73 & 76.13 & 184.19 & 114.68 \\
\hline Farmers & 208.11 & 244.47 & $28,450.62$ & 137.09 & 222.49 & 151.83 & 649.28 & 104.93 & 10.10 & 159.36 \\
\hline $\begin{array}{l}\text { Self-employed } \\
\text { individuals }\end{array}$ & 176.92 & 182.96 & 236.75 & 165.87 & . & 185.86 & 527.46 & 107.92 & 712.20 & 156.93 \\
\hline Pensioners & 182.09 & 197.14 & 197.39 & 185.87 & . & 207.86 & 125.97 & 128.15 & 214.62 & 141.64 \\
\hline Pensioners & 165.44 & 179.02 & 193.41 & 208.47 & . & 183.22 & 129.04 & 133.70 & 180.71 & 128.69 \\
\hline $\begin{array}{l}\text { Disability } \\
\text { pensioners }\end{array}$ & 188.69 & 202.48 & 168.48 & . & . & 216.03 & 227.93 & 165.65 & 514.71 & 152.23 \\
\hline \multicolumn{11}{|c|}{ By the number of people in the household } \\
\hline $\begin{array}{l}\text { 1-person } \\
\text { household }\end{array}$ & 155.53 & 171.89 & 257.25 & 255.74 & 148.88 & 90.88 & 118.19 & 212.51 & 121.71 & 155.53 \\
\hline $\begin{array}{l}\text { 2-person } \\
\text { household }\end{array}$ & 114.12 & 117.19 & 122.64 & 171.63 & 107.66 & 140.10 & 128.71 & 118.89 & 106.16 & 114.12 \\
\hline $\begin{array}{l}\text { 3-person } \\
\text { household }\end{array}$ & 117.41 & 114.60 & 134.16 & 122.84 & 104.45 & 66.57 & 97.52 & 135.50 & 125.43 & 117.41 \\
\hline $\begin{array}{l}\text { 4-person } \\
\text { household }\end{array}$ & 103.99 & 108.88 & 114.76 & 108.54 & 106.69 & 89.50 & 91.07 & 102.64 & 91.24 & 103.99 \\
\hline $\begin{array}{l}5 \text {-person } \\
\text { household }\end{array}$ & 99.26 & 104.93 & 105.01 & 99.59 & 107.36 & 114.40 & 97.80 & 116.80 & 81.60 & 99.26 \\
\hline $\begin{array}{l}\text { 6-or-more-per- } \\
\text { son household }\end{array}$ & 107.87 & 106.89 & 105.12 & 109.16 & 108.30 & 103.46 & 103.79 & 98.63 & 111.78 & 107.87 \\
\hline
\end{tabular}

Source: own study based on Statistics Poland, 2001; 2020.

and the production cycle volume, which depends on the type of conducted activities, are the reasons for the highest diversification of income of agricultural households (Średzińska, 2017).
There was relatively high diversification in average monthly available income per capita between individual economic and social groups of households in the analysed period. In 2019, similarly to the previous years, 
Kozak, J. M., Mrówczyńska-Kamińska, A. (2021). Receipts and income of households in Poland. J. Agribus. Rural Dev., 1(59), 101-115. http://dx.doi.org/10.17306/J.JARD.2021.01431

Table 3. Characteristics of real receipts and disposable income (month/person) of households in total by economic and social groups and by the number of persons in the household in Poland in 2000-2019

\begin{tabular}{|c|c|c|c|c|c|c|}
\hline $\begin{array}{c}\text { Type of } \\
\text { household }\end{array}$ & $\begin{array}{c}\text { Net receipts/ } \\
\text { Disposable income }\end{array}$ & $\begin{array}{l}\text { Minimum* } \\
\quad(\text { PLN })\end{array}$ & $\begin{array}{l}\text { Median* } \\
(\text { PLN) }\end{array}$ & $\begin{array}{l}\text { Maximum* } \\
\quad(\text { PLN) }\end{array}$ & $\begin{array}{l}\text { Coefficient of } \\
\text { variation } \\
(\%)\end{array}$ & $\begin{array}{c}\text { Medium-term } \\
\text { rate of change } \\
(\%)\end{array}$ \\
\hline \multirow[t]{2}{*}{ In total } & Net receipts & $1,267.02$ & $1,789.81$ & $2,321.20$ & 19.91 & 3.07 \\
\hline & Disposable income & 912.71 & $1,359.44$ & $1,819.14$ & 23.15 & 3.51 \\
\hline \multicolumn{7}{|c|}{ By economic and social groups } \\
\hline \multirow[t]{2}{*}{ Workers } & Net receipts & $1,350.86$ & $1,777.52$ & $2,313.90$ & 18.79 & 2.73 \\
\hline & Disposable income & 982.61 & $1,366.73$ & $1,832.14$ & 22.16 & 3.16 \\
\hline \multirow{2}{*}{$\begin{array}{l}\text { Employees } \\
\text { at blue-collar } \\
\text { positions }\end{array}$} & Net receipts & $1,033.71$ & $1,279.61$ & $1,885.46$ & 23.04 & 3.05 \\
\hline & Disposable income & 774.31 & $1,021.46$ & $1,549.93$ & 26.14 & 3.53 \\
\hline \multirow{2}{*}{$\begin{array}{l}\text { Employees at } \\
\text { white-collar } \\
\text { positions }\end{array}$} & Net receipts & $1,890.74$ & $2,355.03$ & $2,762.43$ & 12.56 & 1.91 \\
\hline & Disposable income & $1,337.19$ & $1,814.07$ & $2,127.60$ & 16.20 & 2.35 \\
\hline \multirow[t]{2}{*}{ Farmers } & Net receipts & $1,190.23$ & $1,814.58$ & $2,476.96$ & 23.46 & 3.73 \\
\hline & Disposable income & 681.70 & $1,102.45$ & $1,666.55$ & 30.99 & 4.57 \\
\hline \multirow{2}{*}{$\begin{array}{l}\text { Self-employed } \\
\text { individuals }\end{array}$} & Net receipts & $1,546.89$ & $2,222.73$ & $2,736.79$ & 18.00 & 2.89 \\
\hline & Disposable income & $1,188.02$ & $1,673.49$ & $2,173.63$ & 19.69 & 3.07 \\
\hline \multirow[t]{2}{*}{ Pensioners } & Net receipts & $1,266.25$ & $1,783.56$ & $2,305.72$ & 19.74 & 3.04 \\
\hline & Disposable income & 922.81 & $1,345.76$ & $1,819.27$ & 22.43 & 3.45 \\
\hline \multirow[t]{2}{*}{ Pensioners } & Net receipts & $1,425.52$ & $1,879.05$ & $2,358.39$ & 16.86 & 2.55 \\
\hline & Disposable income & $1,041.03$ & $1,418.64$ & $1,863.61$ & 19.63 & 2.95 \\
\hline \multirow{2}{*}{$\begin{array}{l}\text { Disability } \\
\text { pensioners }\end{array}$} & Net receipts & $1,019.76$ & $1,402.50$ & $1,924.16$ & 21.98 & 3.23 \\
\hline & Disposable income & 739.82 & $1,054.92$ & $1,498.01$ & 24.12 & 3.59 \\
\hline \multicolumn{7}{|c|}{ By the number of persons in the household } \\
\hline \multirow{2}{*}{$\begin{array}{l}\text { 1-person } \\
\text { household }\end{array}$} & Net receipts & $2,069.27$ & $2,780.48$ & $3,218.36$ & 14.11 & 2.23 \\
\hline & Disposable income & $1,394.64$ & $2,045.06$ & $2,397.23$ & 17.55 & 2.75 \\
\hline \multirow{2}{*}{$\begin{array}{l}\text { 2-person } \\
\text { household }\end{array}$} & Net receipts & $1,744.44$ & $2,412.50$ & $2,932.70$ & 16.57 & 2.63 \\
\hline & Disposable income & $1,257.87$ & $1,839.42$ & $2,282.04$ & 19.50 & 3.02 \\
\hline \multirow{2}{*}{$\begin{array}{l}\text { 3-person } \\
\text { household }\end{array}$} & Net receipts & $1,452.04$ & $2,022.86$ & $2,505.29$ & 18.01 & 2.76 \\
\hline & Disposable income & $1,044.04$ & $1,503.05$ & $1,964.80$ & 21.45 & 3.21 \\
\hline \multirow{2}{*}{$\begin{array}{l}\text { 4-person } \\
\text { household }\end{array}$} & Net receipts & $1,186.74$ & $1,559.35$ & $2,112.65$ & 20.70 & 2.93 \\
\hline & Disposable income & 860.71 & $1,216.28$ & $1,675.92$ & 23.94 & 3.39 \\
\hline \multirow{2}{*}{$\begin{array}{l}\text { 5-person } \\
\text { household }\end{array}$} & Net receipts & 956.91 & $1,236.42$ & $1,818.77$ & 23.41 & 3.26 \\
\hline & Disposable income & 694.14 & 971.35 & $1,450.44$ & 26.66 & 3.75 \\
\hline \multirow{2}{*}{$\begin{array}{l}\text { 6-or-more-per- } \\
\text { son household }\end{array}$} & Net receipts & 746.21 & $1,041.87$ & $1,560.53$ & 26.87 & 3.76 \\
\hline & Disposable income & 536.79 & 804.80 & $1,259.08$ & 31.08 & 4.35 \\
\hline
\end{tabular}

*Month/person.

Source: own study based on Statistics Poland, 2001; 2007; 2009; 2011; 2015; 2018; 2020. 


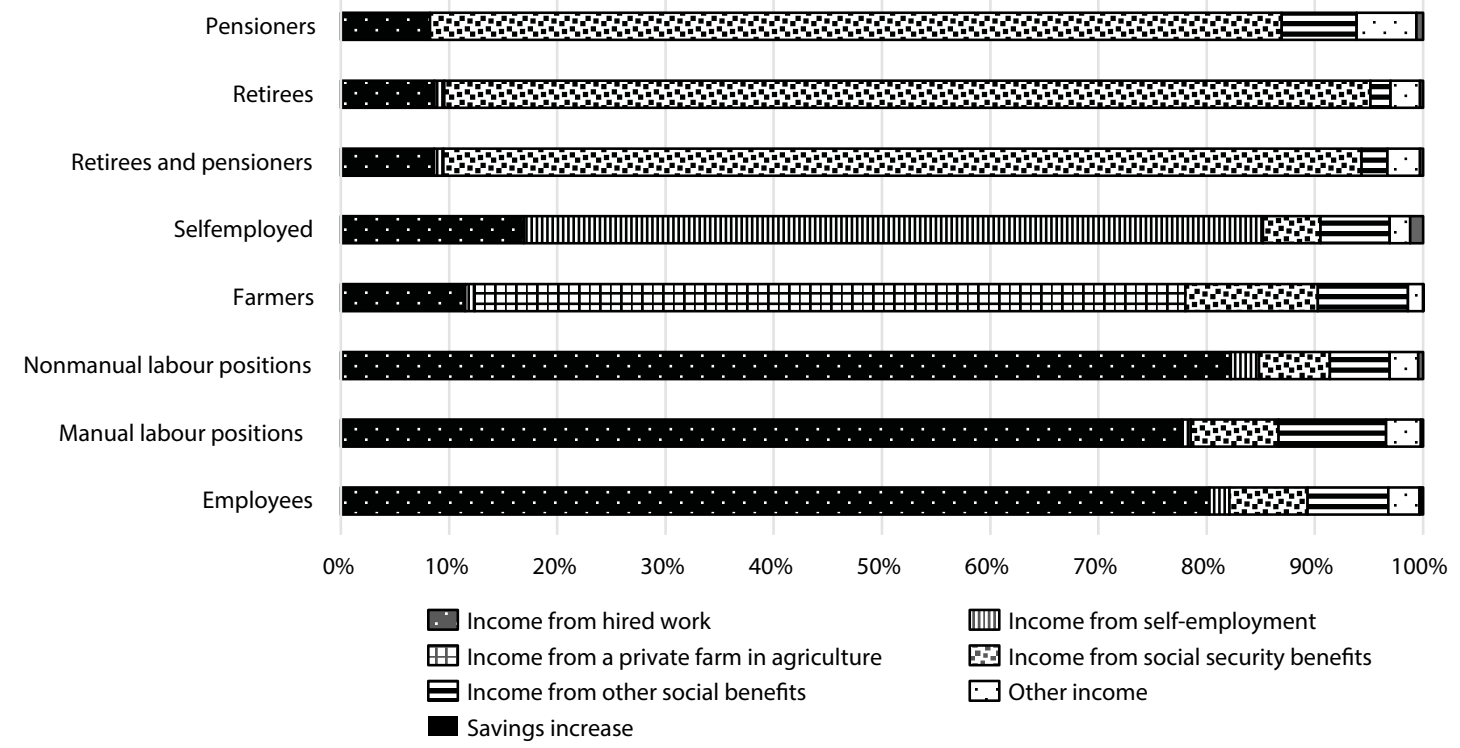

Fig. 5. The structure of average monthly available income per capita in real terms in households by economic and social groups in Poland in $2019(\%)$

Source: own study based on Statistics Poland, 2001, 2020.

the highest average monthly income was recorded for white-collar workers and self-employed individuals except for agricultural farms (ca. PLN 2,100 in 2019). Income in these groups of households was higher, by ca. $17 \%$ and $19 \%$, respectively, than the available income in total households.

The lowest average monthly available income per capita in 2019 and previous years was recorded for households of pensioners (in 2019 - PLN 1,500) and blue-collar workers (PLN 1,550); it was lower by ca. $18 \%$ and $15 \%$ than the total average available income. However, it should be noted that available income in both groups in 2019 was higher than in 2000 by more than $100 \%$ and ca. $102.5 \%$, respectively, and the average annual rate of change was $3.5 \%$ and $3.6 \%$; the coefficient of variation of available income was high; it was at the level of ca. $26 \%$ and $24 \%$ (Table 3). The low level of income in pensioner households results from their use of non-earned sources of income, which depend on the type of benefit received, and thus on health and the determination of ability to work ${ }^{1}$. The increasing level

${ }^{1}$ Dz. U. 1998, No 162, item 1118, consolidated text, the Act of 17 December 1998 on Retirement Pensions and Other Pensions from the Social Insurance Fund. of income for this group and retirees can be attributed to the government policy, i.e. the indexation of social benefits (Kozera and Wysocki, 2014).

The highest average monthly increase of available income in real terms was observed in farmers, namely ca. $144.5 \%$ in 2019 compared to 2000 , with an increase of income from private farms in agriculture by ca. $122.5 \%$ and income from social assistance benefits increased almost 6.5 times. The increase in income of farmer households largely resulted from the inclusion in 2004 of the Polish agricultural sector in the EU Common Agricultural Policy and open EU markets; and, consequently, the support received in the form of subsidies from EU programmes. Support from the state budget, development of entrepreneurship and extending private initiative in rural areas also contributed to the stabilisation and improvement in income from agriculture in relation to other professional groups (Lacka, 2017; Dudek, 2014).

In turn, the lowest increase in income, ca. 59\% and $79 \%$, was observed in households of white-collar workers and retirees. The lowest income increase in retirees can be attributed to non-earned income received by this group, while the generated income decreases over time. Also, the lowest level of medium-term rate of change 
of income received by retirees was noted compared to other groups, and it amounted to almost $3 \%$. The coefficient of variation of income for retiree households was almost $20 \%$. There was an increase in available income in 2019 compared to 2000 by over $86 \%$ in the total group of employed persons. This income is predominantly generated from hired labour whose share in the available income is $80-84 \%$. The coefficient of variation of income of employed persons amounted to ca. $22 \%$, which was related to the profession and the blue-collar or white-collar position held by household members, and the medium-term rate of change was over $3 \%$. From 2000 to 2019, the income share from the main source in the available income was between $65 \%$ and $86 \%$ in all economic and social groups.

Net receipts, except for available income, are also included as savings on the revenue side. It was observed that in 2019 they increased in all the analysed groups compared to 2000 (Table 2). The highest level of savings on the revenue side from 2000 to 2019 was observed in farmers (ca. PLN 810 in 2019, which is 59\% more than in 2000). In turn, the lowest level was observed in bluecollar workers (almost PLN 336 in 2019, which is more than $29 \%$ more than in 2000).

Over the years, the share of savings on the revenue side in net receipts for all households decreased, and their amount usually increased, which can mean better creditworthiness related to the increasing income and, therefore, receiving credits and loans (Wałęga, 2010).

It should be noted that the net receipts and available income of households of blue-collar workers, farmers and pensioners with the worst income situation among the analysed groups increase more rapidly compared to households with the best income situation (households of white-collar workers and self-employed individuals). Medium-term increase of receipts and available income in households of blue-collar workers, farmers and pensioners ranged from ca. $3.0 \%$ to over $5.0 \%$. In turn, in households of white-collar workers and self-employed individuals, it ranged from ca. $2.0 \%$ to $3.0 \%$ (Tables 2 and 3 ).

The Gini coefficient reflects income inequality in society; it is also referred to as the social inequality inde $x^{2}$. The value of the Gini coefficient in relation to

${ }^{2}$ This coefficient was formulated by an Italian statistician Corrado Gini, born on 23 May 1884. In economics, Gini mainly analysed the issues related to the "wealth of nations" and state the income of total households and particular types of households in Poland from 2003 to 2019 is presented in Fig. 6.

For OECD countries, there is a widespread classification regarding the variation in the distribution of household income, according to which the Gini coefficient between 33 and $35 \%$ characterises a high degree of inequality, 29-32\% - medium, 25-28\% - low, and $20-24 \%$ - a very low degree of income inequality (Bilan et al., 2020).

For total Polish households in the analysed years, the Gini coefficient ranges from 0.298 to 0.345 . The value of this coefficient was higher from 2003 to 2013. However, this value has been decreasing since 2014, which is a positive phenomenon as the available income gap among households decreases. However, according to the classification for OECD countries, this is an average degree of inequality.

A decreasing value of social inequality also means that the income gap among Polish households is typical for the irregularity of income distribution in developed economies. The reason for the decreasing disparity can be seen in the activities of the state in the sphere of social spending and the decreasing level of unemployment (from 13. 4\% in December 2013 to $11.4 \%$ in December 2014) (GUS). A rising share of social spending promotes redistribution through transfers and taxes while reducing inequality to a greater extent (Szczepaniak, 2018). However, it should be noted that despite

budget, and their analysis based on such wealth sources. As he was interested in aspects related to society, i.e. income and social welfare, he formulated an index of income concentration. The idea of the Gini coefficient began to take shape in 1909. Initially, it was inspired by the Pareto index and "average differences" (Ostasiewicz, 2013). Ultimately, the Gini coefficient is a measure of income distribution inequality, which takes values from 0 to 1 , and a percentage value can be obtained if this value is multiplied by 100 . When the value of the coefficient is 0 , the interpretation is that all people receive the same income, and when the value reaches the maximum, all persons, except for one, receive zero income or, in other words, it means maximum diversification of income in a particular group, which is extreme inequality. The higher the value of the coefficient, the higher the level of income concentration and its diversification. In the works by the said author, it can be noted that empirical values of the Gini coefficient range from 0.2 to 0.5 , where 0.5 indicates a very high diversification of income. It is assumed that this coefficient ranges from 02.6 to 0.33 based on taxable income in countries with highly developed economies that have a very well-developed system of social benefits (Szopa, 2006). 


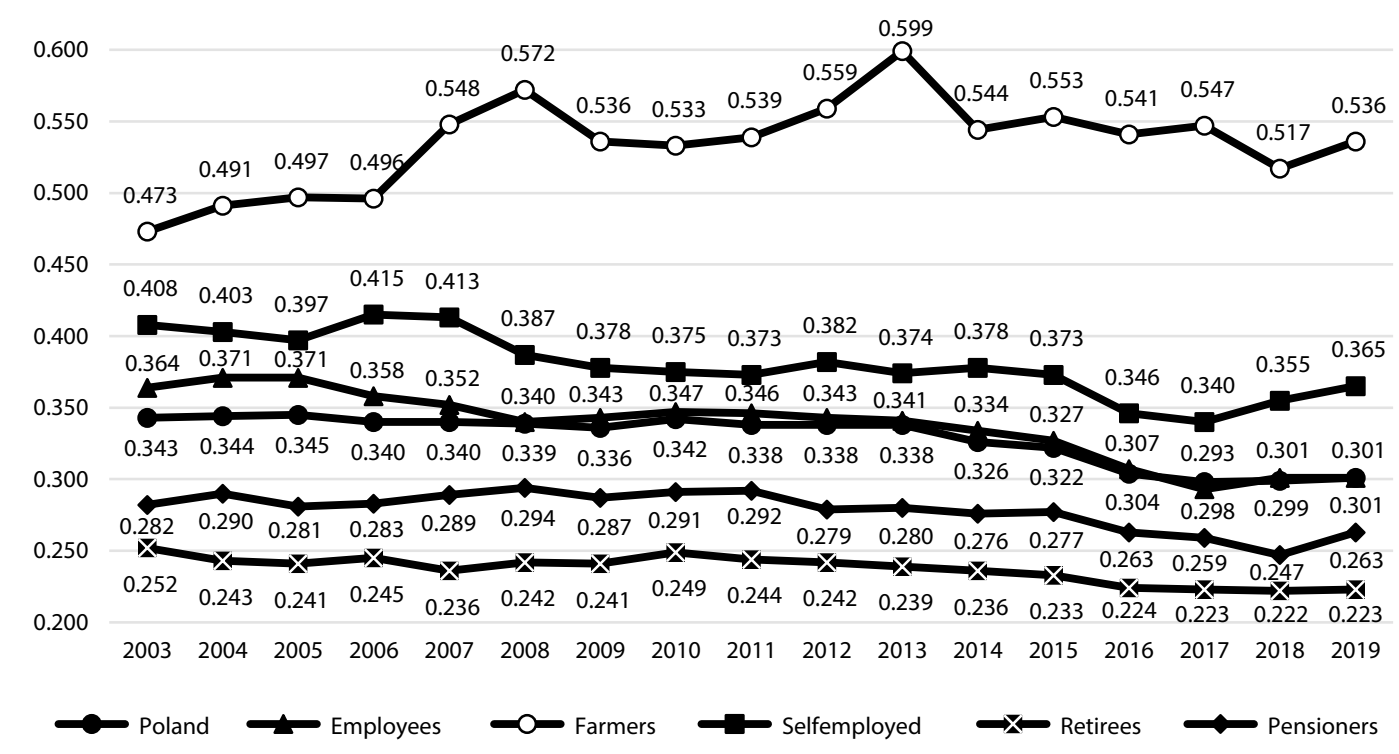

Fig. 6. The diversification of average monthly income measured with the Gini coefficient, in total and by the economic and social group in Poland from 2003 to 2019

Source: own study based on Statistics Poland, 2004-2020.

the small differences in total household income, much higher diversification was observed within particular economic and social groups.

Based on studies on the equalisation of household income in EU member states from 2007 to 2015, absolute beta-convergence can be observed, i.e. the household income increase in less affluent countries is faster than in rich ones, in particular in countries similar in economic and institutional terms, that is in EU member states. It is also emphasised that the convergence of income resulted, in particular, from increasing income in the countries of Central and Eastern Europe, with a significant positive influence on the convergence of household income exerted by Poland, which together with Bulgaria and Slovakia, demonstrated the highest rate of increase of the analysed income compared to other countries (Muszyńska et al., 2018).

When considering the differences in economic and social groups, it should be noted that the most significant diversification in the studied years was observed in farmers. The income gap in this group, illustrated by the Gini coefficient, ranged from 0.473 to 0.599 in the analysed period. Such a high value of the inequality index was not observed in any other economic or social group. From 2006 to 2008, there was an increase in this coefficient. It resulted from sharp increases in prices (starting in mid-2008) of some essential agricultural produce (for example, cereals, dairy products, meat). The changes that took place in those years were also caused by speculations on financial markets related to agricultural raw materials, intensification of interactions between markets of agricultural products, caused by demographic growth, high economic growth rates, urbanisation processes, or changes in eating habits (Parlińska and Wielechowski, 2009). It can be assumed that agricultural policy and the allocation of funds from the EU budget are one of the most important factors influencing the diversification of the household income gap in agriculture (in particular the transfer in the form of direct payments) (Bryła, 2010; Institute..., 2020).

Differences in the income of farmer households may be due to many other reasons, such as natural conditions (soil quality, sun exposure, rainfall and temperature), size and type of farm, and the agricultural production profile. It is important because some areas of agricultural production are more or less labour-intensive and time-consuming. Fragmentation of the agrarian structure may also influence this. Another reason for income diversification may be the farmers' involvement in 


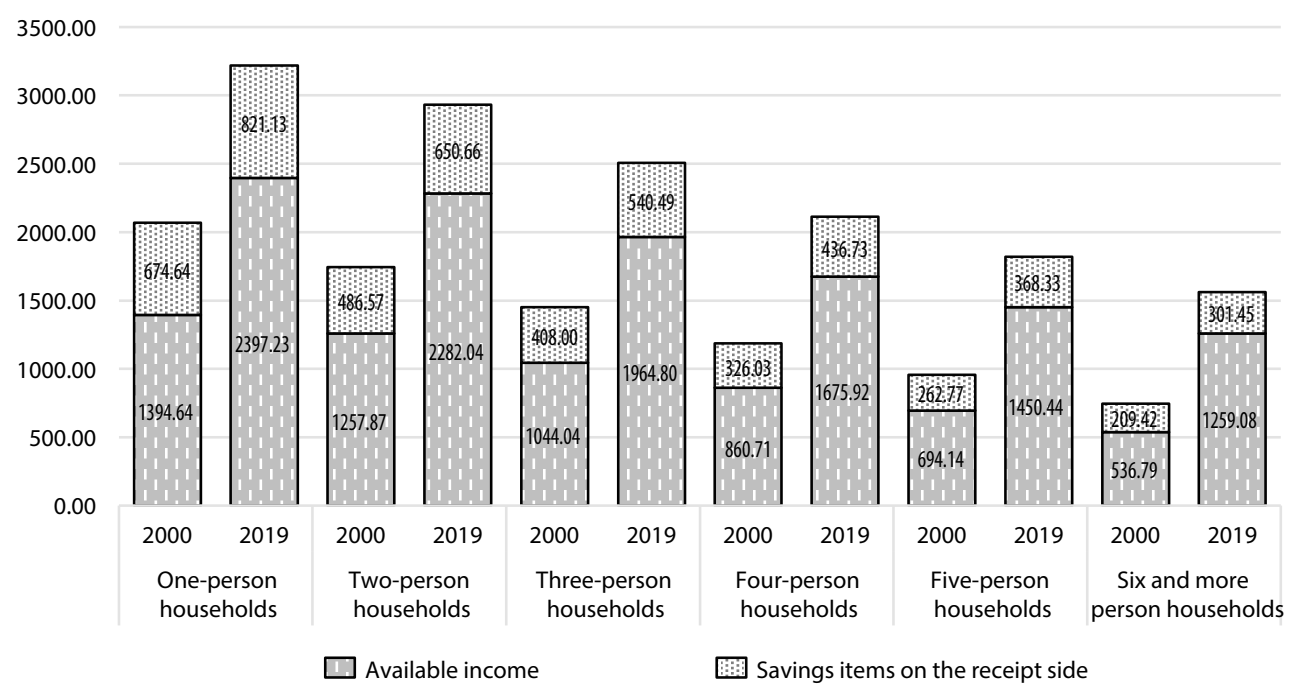

Fig. 7. Average monthly net receipts per capita in real terms in households by the number of persons in Poland in 2000 and 2019 (PLN)

Source: own study based on Statistics Poland, 2001; 2020.

non-agricultural activities, thus obtaining an additional income source. The differences in farmers' income are also significantly influenced by personal characteristics such as competence and skills, entrepreneurship and attractiveness on the labour market outside agriculture, and the availability of alternative income opportunities. The income gap between farmers is also influenced by competition and the technologies used (Niezgoda, 2009). All these factors indicate that agricultural households are one of the most diverse types of households.

The least diverse household income was observed in pensioners. In 2003-2019, the Gini coefficient was $0.222-0.252$. It means that the income gap in pensioner households is small, and the fluctuations in the income gap in the analysed years are small between individual years. Different pension benefits may cause this gap, the amount of which depends, among other things, on the length of service; however, the difference is not significant since the payment of pension benefits is governed by a law that ${ }^{3}$ applies to the whole of society.

In worker households, the Gini coefficient in 20032019 was between 0.293 and 0.371 . It is similar to, and in 2008 it almost coincided with, the level of this

${ }^{3}$ Dz. U. No. 162 , item 1118 , consolidated text, the Act of 17 December 1998 on retirement pensions and other pensions from the Social Insurance Fund. ratio for total household disposable income. The value of the social inequality index in workers' incomes is also small, although it is higher than that of pensioners $(0.247-0.294)$. It should be noted that the income gap in the pensioner group is greater than in the households of retired people, which may result from the receipt of different social security benefits, as many pensioners are disabled or chronically ill, and thus have a weak standing on the labour market (Gasińska, 2016). Analysing the income gap between self-employed individuals' households ranging from 0.340 to 0.415 in the studied years, it should be pointed out that this ratio is decreasing, which is a positive phenomenon.

Since the beginning of the decade, just like in other economic and social groups, the average income of households by the number of their members has varied. Such diversification results from the number of persons living in a household and, above all, income sources.

The highest average net receipts in real terms, amounting to almost PLN 2,100 per capita (2000) and over PLN 3,200 per capita (2019), were recorded in one-person households. Over the years, revenues in this group increased by ca. 56\% in 2019 compared to 2000 . The highest average available income per capita during the 20 years covered by the study was observed in one-person households (Fig. 7). Over the years, income in this group increased by $72 \%$ in real terms in 2019 
compared to 2000 . The real monthly receipts and available income in these households demonstrated variations at the level of over $14 \%$ and almost $18 \%$, respectively, and on average, they increased by ca. $2.2 \%$ and $2.8 \%$ per year.

A significant part of available income in one-person households was income from hired work (i.e. $22-33 \%$ ) and social security (i.e. $50-60 \%$ ). The reason for such a predominance of income from social insurance in disposable income may be that most single-person households are people of post-working age, whose primary income source is their pension. In 2019, income in oneperson households was almost $32 \%$ higher than the total average available income of households.

The lowest average net receipts and available income were recorded in households of six or more persons. In the last nineteen years, the average net receipts per person have increased by more than $109 \%$ (on average, from PLN 537 to almost PLN 1,260 per person). Despite still showing the lowest income in all the studied groups according to the number of persons in the household, these families have also seen an improvement in the financial situation (Fig. 7). However, they still have ca. 2-2.6 times less money per person than single-person households. It should be noted that the income gap between these groups is decreasing over the years. The disposable income of families of six or more has changed by ca. $135 \%$, meaning that in 2019 , households earned ca. PLN 716 more than in 2000. In six-or-more-person households, the real net receipts and disposable income per person were characterised by the highest variability compared to other groups of households according to the number of persons in the analysed years, and the coefficient of variability was almost $27 \%$ and over $31 \%$. Thus, in these households, net receipts and disposable income increased the fastest, i.e. by nearly $3.8 \%$ and $4.4 \%$ on average (Table 3).

The average available income in a family of six or more consists primarily of income from hired work (about 41-53\%), social security benefits (about 14$21 \%$ ) and individual household in agriculture (about 10-16\%). However, the most significant change occurred in the income from social assistance benefits. In 2000, income from social assistance benefits amounted to less than $10 \%$ of the total available income, while in 2019 , it was over 19\%. It indicates that households of six or more have income from social assistance benefits which in 2019 is about $361 \%$ higher than in 2000 . Such a significant change results from the increasing involvement of state aid for the poorest and multiple-children families. In 2016, a family income-supporting benefit, the so-called Family 500+ Programme, has been introduced, aiming to provide material assistance to partially cover expenditures related to raising children and satisfying their fundamental needs ${ }^{4}$. It is also possible to notice a shift in the structure of available income in three-person households. In the initial period of the programme's operation, the $500+$ benefit was available for families with two or more children. In 2019, the programme was modified to include every child up to the age of 18, regardless of the amount of income earned by the family (the Ministry of Family, Labour and Social Policy ${ }^{5}$. During the analysed years, an increasing average value of savings on the revenue side per person may be observed in all groups according to the number of persons in the household. The highest value of savings on the revenue side during the examine years was recorded in single-person households (PLN 675 in 2000 - PLN 821 in 2019, i.e. approximately $22 \%$ more), while the lowest in households of six or more (209 PLN in $2000-301$ PLN in 2019 , i.e. about $44 \%$ more). On this basis, it can be concluded that the increasing income motivates household members to take out loans and credits.

It should also be noted that the share of the savings on the revenue side in net receipts is decreasing in all analysed groups due to the number of household members. In 2019, the share of said savings in all studied groups decreased compared to 2000 - in single-person households by more than seven percentage points while in households of six or more by approximately nine percentage points (Fig. 8).

Similarly to households of blue-collar workers, in the case of farmers and pensioners, who are characterised by the least favourable income situation among the surveyed groups, net receipts and available income in households of six or more persons increase faster than in households with a better income situation (Table 2, Table 3).

${ }^{4}$ Dz.U.2017.1851.i.e. Journal of Laws of 5 October 2017, Act of 11 February of 2016 on State Assistance in Raising Children.

${ }^{5}$ Dz. U., item 924, i.e. Act of 26 April 2019 on the amendment of the Act on State Assistance in Raising Children and Certain Other Acts. 


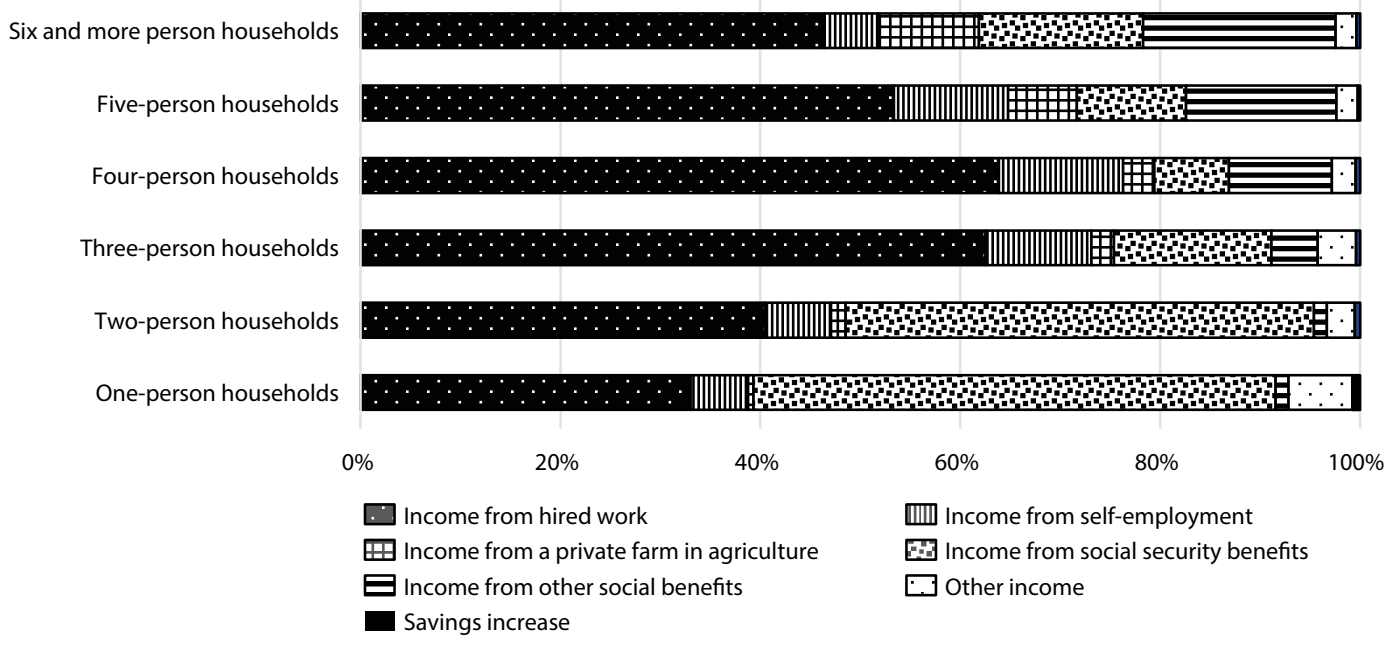

Fig. 8. Structure of an average monthly available income per household member in real terms in Poland in 2019 (\%), according to the number of household members Source: own study based on Statistics Poland, 2001; 2020.

\section{SUMMARY AND CONCLUSIONS}

During the analysed period, the income situation of households in general and according to economic and social groups and the number of household members in Poland indicated a real increase in average monthly net receipts and available income in all studied groups. The improvement in Polish households' income situation has been influenced mainly by the systemic transformation, the improving situation on the labour market, the minimum wage increase, and social assistance from the state (the $500+$ benefit). The conducted analysis proved that during the examined period, the relatively most favourable income situation was found in households of white-collar workers and self-employed and single-person households, while the least favourable income situation was recorded in the households of blue-collar workers, pensioners and households of six or more persons. It was observed that in households with the worst income situation, net receipts and available income increase faster than in households with the best income situation, which is indicated by the highest medium-term rate of change in these groups. Faster growth of receipts and income in households of blue-collar workers, farmers and pensioners may result from various reasons, e.g. the minimum wage increase or support received from the European Union (direct benefits). Income inequalities between Polish households, illustrated by the Gini coefficient, are consistent with inequalities occurring in economically developed countries with an extensive social benefits system. The most considerable income disparity was found in agricultural households, while the least significant in pensioner households.

\section{REFERENCES}

Act of 11 February 2016 on State Assistance in Raising Children, Dz.U.2017.1851.

Act of 21 June 2001 on Housing Benefits. Dz.U. No. 71, item 734

Act of 17 December 1998 on Pensions from the Social Insurance Fund. Dz.U. No. 162, item 1118.

Bilan, Y, Mishchuk, H., Samoliuk, N., Yurchyk, H. (2020). Impact of Income Distribution on Social and Economic Well-Being of the State. Sustainability, 12(1), 429.

Bryła, P. (2010). Uwarunkowania zróżnicowania dochodów rolniczych w Unii Europejskiej [Determinants of agricultural income diversification in the European Union]. Zesz. Nauk. SGGW Warsz. Ekon. Org. Gosp. Żywn., 80, 5-17.

Casimir, G.J., Tobi, H. (2011). Defining and using the concept of household: a systematic review. Int. J. Cons. Stud., 35(5), 498-506.

Dudek, A. (2014). Koniunktura w polskim rolnictwie na tle sytuacji ogólnogospodarczej w latach 1996-2012 [The situation in Polish agriculture against the general economic 
situation in 1996-2012]. Rocz. Nauk. Ekon. Roln. Rozw. Obsz. Wiej., 101(2), 7-19.

Drymluch, M., Chorkowy, B. (2009). Próba oceny zachowań gospodarstw domowych po wejściu Polski do Unii Europejskiej [An attempt to assess the behavior of households after Poland's accession to the European Union]. In: T. Bernat (ed.), Teoretyczne i praktyczne aspekty funkcjonowania gospodarki [Theoretical and practical aspects of the functioning of the economy] (pp. 235-245). Szczecin: University of Szczecin.

Gasińska, M. (2016). Dochody gospodarstw domowych w Polsce - wybrane obiektywne i subiektywne ujęcia i dane [Household income in Poland - selected objective and subjective approaches and data]. Zesz. Nauk. Ucz. Vistula, 50(5), 100-142.

GUS (2011). Metodologia Badania Budżetów Gospodarstw Domowych [Statistics Poland Social Surveys and Living Conditions Department]. Warszawa: Główny Urząd Statystyczny.

Grzega, U. (2007). Wpływ wybranych makrouwarunkowań i czynników ekonomicznych na zachowania gospodarstw domowych [The influence of selected macro-conditions and economic factors on the behavior of households]. In: D. Kopycińska (ed.), Działania ekonomiczne podmiotów rynkowych [Economic activities of market entities]. Conference materials from the International Conference „Ekonomiczne wyzwania XXI wieku, Polska-Unia Europejska-Świat" organised by the Department of Microeconomics at the University of Szczecin as part of the 4th National Congress of Economic Departments (pp. 129-139). Szczecin: Print Group.

Inglot-Brzęk, E. (2010). Społeczno-ekonomiczne procesy modernizacji gospodarstw domowych w Polsce w okresie transformacji systemowej [Socio-economic processes of modernization of households in Poland in the period of systemic transformation]. Nierów. Społ. Wzrost Gosp., $17,265-277$.

Institute of Agricultural and Food Economics (ed.) (2020). Rolnictwo i gospodarka żywnościowa w Polsce [Agriculture and food economy in Poland]. Warszawa: Ministry of Agriculture and Rural Development.

Kozera, A., Wysocki, F. (2014). Sytuacja finansowa gospodarstw domowychrolników natlepozostałych grup społeczno-ekonomicznych ludności [Financial situation of farmers' households compared to other socio-economic groups of the population]. J. Agribus. Rural Dev., 3(33), 85-99.

Kramer, J. (2004). Struktura otoczenia polskich gospodarstw domowych - próba klasyfikacji [The structure of the environment of Polish households - an attempt at classification]. Acta Univ. Lodz. Folia Oecon., 179, 121-130.
Łącka, I. (2017). Sytuacja dochodowa wiejskich gospodarstw domowych w Polsce w latach 2007-2014 i jej skutki [Income situation of rural households in Poland in 20072014 and its effects]. Probl. Drob. Gosp. Roln., 1, 29-42.

Mazurek-Krasodomska, E. (2017). Dochody gospodarstw domowych i ich determinanty - zróżnicowanie regionalne w UE [Household income and its determinants - regional differentiation in the EU]. Ann. UMCS Lublin - Polonia, LI, 5(H), 189-197.

Michorowski, M., Pollok, A., Szopa, B. (2016). Transformations in the sphere of household income in Poland by socio-economic groups in 1993-2014. Wrocław: Wyd. UE we Wrocławiu.

Muszyńska, J. (2006). Zróżnicowanie dochodowe gospodarstw domowych w Polsce [Income differentiation of households in Poland]. Zesz. Nauk. PWSZ we Włoc. Ekon. Zarz, 1, 412-423.

Muszyńska, J., Oczki, J., Wędrowska, E. (2018). Konwergencja dochodów gospodarstw domowych w krajach Unii Europejskiej [Convergence of household incomes in the European Union countries]. Wiad. Stat. Polish Stat., 11(690), 21-40.

Niezgoda, D. (2009). Zróżnicowanie dochodu w gospodarstwach rolnych oraz jego przyczyny [Income differentiation in farms and its reasons]. Zagad. Ekon. Roln., 318(1), 24-37.

Ögren, A. (2018). Determinants behind Household Saving Behavior - Empirical analysis on 15 OECD countries. Umeå School of Business and Economics (USBE).

Ostasiewicz, K. (2013). Nierówności i faszyzm, czyli życie i dzieło Corrado Giniego. Śl. Przegl. Stat., 11(17), 151-170.

Parlińska, M., Wielechowski, M. (2009). Wpływ globalnego kryzysu finansowego na stan amerykańskiego i polskiego rolnictwa [The impact of the global financial crisis on the condition of American and Polish agriculture]. Zesz. Nauk. SGGW Warsz. Probl. Roln. Świat., 8(23), 152-163.

Pochopień, J., Rykowska, J. (2013). Sytuacja dochodowa oraz materialna gospodarstw domowych w Polsce - w świetle badań GUS [Income and material situation of households in Poland - in the light of GUS research]. Logistyka, 4, 436-443.

Statistics Poland (2001, 2007, 2009, 2011, 2016, 2018, 2020). Household budgets of 2000, 2006, 2008, 2010, 2015, 2017, 2019. Warszawa: Statistics Poland.

Szczepaniak, M. (2018). Nierówności dochodowe w gospodarce światowej w okresie pokryzysowym - wybrane aspekty ekonomiczne i społeczne [Income inequalities in the world economy in the post-crisis period - selected economic and social aspects]. Stud. Ekon., 352, 247-257. 
Szopa, B. (2006). Zróżnicowanie dochodów w Polsce [Income inequality in Poland]. Zesz. Nauk. AE Krak., 744, $105-124$

Śleszyńska-Świderska, A. (2014). Konsumpcja a wzrost gospodarczy w Polsce. W cieniu globalnego kryzysu gospodarczego [Consumption and economic growth in Poland. In the shadow of the global economic crisis]. Nier. Spot. Wzrost Gosp., 38, 352-364.

Średzińska, J. (2017). Zróżnicowanie poziomu dochodów rolników w gospodarstwach o różnych typach rolniczych w krajach Unii Europejskiej [Differentiation of the level of farmers' income on farms of various types of farming in the European Union countries]. Fin. Ryn. Fin. Ubezp., $11(145-155)$.

Światowy, G. (2012). Gospodarstwo domowe jako kreator przemian społecznych i gospodarczych [Household as a creator of social and economic changes]. Kons. Rozw., 2, 56-66.

Świecka, B., Musiał, M. (2014). Zarządzanie finansami gospodarstw domowych $\mathrm{w}$ warunkach pogarszającej się sytuacji makroekonomicznej [Household finance management in conditions of deteriorating macroeconomic situation]. Zesz. Nauk. US. Probl. Zarz. Fin. Mark., 33, 822, 89-98.

Świetlik, K. (2011). Zarządzanie budżetem przez gospodarstwa domowe (aspekty teoretyczne i praktyczne) [Budget management by households (theoretical and practical aspects)]. Hand. Wewn., 5, 3-11.

Urban, S. (2016). Wiejskie gospodarstwa domowe w porównaniu $\mathrm{z}$ innymi typami gospodarstw domowych [Rural households compared with other types of households]. Probl. Drobn. Gosp. Roln., 4, 93-107.

Wałęga, G. (2010). Determinanty zadłużenia gospodarstw domowych w Polsce w świetle wybranych teorii konsumpcji [Determinants of household indebtedness in Poland in the light of selected consumption theories]. In: Z. Dach (ed.), Otoczenie ekonomiczne a zachowania podmiotów rynkowych [Economic environment and the behavior of market entities] (pp. 114-133). Warszawa: PTE.

Wiśniewska, A. (2016). Determinanty nadmiernego zadłużania się polskich gospodarstw domowych [Determinants of excessive indebtedness of Polish households]. Współcz. Fin. Teor. Prakt., 1(1), 91-100.

Wysocki, F., Lira, J. (2005). Statystyka opisowa [Descriptive statistics]. Poznań: Wyd. AR w Poznaniu. 
